\title{
一箇所排水時の排水立て管内平均圧力分布の予測手法
} 超高層住宅における排水立て管内圧力分布に関する研究 その 1

\section{A PREDICTION METHOD OF AIR PRESSURE DISTRIBUTION OF DRAINAGE STACK SYSTEMS IN CASE OF SINGLE-POINT STEADY DISCHARGE}

Study on pressure distribution of drainage stack systems in high-rise apartment houses Prat 1

\author{
鄭 政利*, 鎌田元 康**, 倉 㴊 隆***, 坂上恭助****, 田中徹***** \\ Cheng-Li CHENG, Motoyasu KAMATA, Takasi KURABUTI, \\ Kyousuke SAKAUE and Toru TANAKA
}

\begin{abstract}
Systematic full scale model experiments were performed using a $100 \mathrm{~m}$ class experiment tower in order to simulate actual water discharge of high-rise residential buildings. Preliminary experiments showed that high level of discharge entry leads not only large peak negative pressure but also peak position being apart from the branch entry, which has not been observed in the $30 \mathrm{~m}$ class tower experiments. In order to develop a numerical prediction method of pressure distribution, the drainage stack system is hypothetically divided into four parts and each part is separatively modeled. A new semi-empirical hydraulic model is developed to relate constant pressure gradient at final stack length to stack air flow rate, based on the balance of pressure and frictional forces. Distance between discharge entry and a downstream point of the same recovered air pressure is successfuly modeled as a function of stack air flow rate. Other parts of the drainage stack systems are handled based on the empirically determined friction loss coefficients. Finally, we assembled each model and formed a full numerical prediction method of air pressure distribution of drainage stack systems, which includes prediction of peak negative pressure and stack air flow rate. The calculated results are satisfactory compared to both $108 \mathrm{~m}$ tower and $30 \mathrm{~m}$ tower experiments, in case of single-point steady discharge.
\end{abstract}

Keywords: drainage stack, high-rise buildings, pressure distribution of drainage stack, the peak negative pressure, air flow in stack vent pipe

排水立て管、超高層建物、管内圧力分布予測、最大負压、通気流量

\section{1.はじめに}

建物内の排水システムは、確実な作動が要求されるた め、エネルギーを使用しない重力式排水システムが世界 的に主流となっており、また、排水管内の悪臭・衛生害 虫等の阻止にも、単純な機構の水封トラップの使用が一 般的である。排水を流す際にトラップ内の封水を保護す るため、重力式排水システムの排水立て管内では、満流 で排水を流すことは許されず、固形物を含む排水と空気 が混在する混相流となっている。排水管内の空気の歌動 力は、水が重力で落下する際の水・空気間の摩擦力によ り生じるものの他、一部空気が排水に巻き込まれること により、排水と一体化して流下することによるものであ る。その一方で排水が排水横枝管から排水立て管に流れ 込む位置、及び排水立て管から排水横主管に流机込む位 置では、跳水現象等の複雑な流れが生じることにより、 管の比較的短かい区間で通気断面積が大幅に変化する。
従って、これらの部位ではダクトの急穛小、急拡大部分 と同様な珐力損失が生じ、一部排水と空気の流下速度差 に関連した摩擦応力が生じるものの、主に通気抵抗とし て作用する。このように、重力式排水システムにおける 管内流動は、混相流としての複雑な流れであること、重 力が支配的な要因であり、模型実験が極めて困難なこと などから、特に超高層排水システムについては解明が十 分になされておらず、排水システムの設計が、主に経験 的な算法によってなされている現状にある。

関連する海外の研究として、Pinkは32層規模の建物 （約100m）に設置された排水立て管を用いて、定流量負 荷による排水実験を行っている。その結果得られた知見 で注目すべき点は、排水負荷階が高くなるに従い、通気 流量が増加することが挙げられ、負荷高さの相違による 通気流量が管内圧力分布の予測法確立のポイントとなる ことが指摘されている。日本では、大塚らが $30 \mathrm{~m}$ 級 $(10$
* 東京大学大学院工学系研究科 大学院生

** 東京大学大学院工学系研究科 教授.工博

*** 東京理科大学工学部建築学科 助教授. 工博

**** 明治大学理工学部建築学科 助教授. 工博

***** 佐藤総合計画(侏 I修
Graduate Student, Dept. of Architecture, Univ. of Tokyo Prof., Dept. of Architecture, Univ. of Tokyo, Dr. Eng.

Associate Prof., Dept. of Architecture, Science Univ. of Tokyo, Dr. Eng.

Associate Prof., Dept. of Architecture, Univ. of Meiji, Dr. Eng. AXS SATOW INC., M. Eng. 
層規模）の実験タワーを用いた排水実験により、管内圧 力分布の予測手法を提案している。同手法は超高層への 対応をも考虑し、また、Pink等の実験結果との比較検討 も行っているが、超高層排水システムを直接模擬できる 装置を用いた検証実験は行っていない。

この点に関し、筆者らは住宅・都市整備公団の八王子 試験所内に設置された高さ $108 \mathrm{~m}$ の実験タワーの使用機 会を得たので、実際の超高層住宅を模擬した一連の排水 実験を実施した。本報では、実験の結果得られた新たな 知見について述へるとともに、実験結果を整理・統合す ることにより開発した超高層にも適用可能な、新たな管 内珐力分布予測法の概要について述へる。

なお、本報では、これまで十分な解明がなされていな い超高層を含む任意高さの排水管における複雑な流れ現 象のモテル化とその妥当性の検証を主たる目的としたの で、検討対象を極力単純化し以下に示す条件に限定した。 (1)対象排水システムは伸頂通気方式とする。

(2)排水としては排水立て管に接続する排水横枝管 1 筒所 からの定常排水のみを考慮する。

(3)排水には固形物を含めず、水亡空気のみの気液二相流 を想定し、洗剂混入もないものとする。

また、現象のモデル化に際し以下を基本方針とした。

(1)排水管内の気相、液相の管内分布等のモテル化を行う ことは当面行わず、平均通気速度等の断面平均値のみ を考虑する。

(2)排水立て管への排水の流入部及び排水立て管と横主管 結合部で生じる圧力損失は、ダクトにおける断面形状 変化による抵抗と類似した取扱いが可能とする。

(3)排水立て管内の空気駆動力は空気と空気に接触する排 水との落下速度の差に起因した摩擦力が主たるもので あり、排水と一体化して落下する空気の影響は小さい ものとする。

\section{2. 既往研究との䦥迫}

重力式排水システムの管内流動に関する最初の研究亡 しては、1940年代にR. B. Hunter1)により行われたものが举 げられるが、測定機器の制約などもあり、定性的な記述 にとどまっている。給排水設備に関する国際会議として 継続的に開催されているのは、C I B W-6 2のセミ ナ一のみであるが、そこで発表される論文でむ、定量的 かつ解析的に記述されたものは非常に少ない。また、実 験結果に関しても先に述べたように $100 \mathrm{~m}$ 規模の実験夕 ワーを用いたものは、B. J. Pink2)の一例のみである。

国内では、大塚他 (4) と根路銘ら5)が管内圧力予測法に関 し報告しており、大塚らの提案は先述したように超高層 建物への搪張可能性を踏まえたものであるが、30m 級の夕 ワーの実験結果からの外挿の域を出ず、超高層固有の現 象への適用には限界がある。

本研究では、従来、その平均的な梯相さえも十分には
解明されていなかった超高層住宅における重力式排水シ ステムの管内流動現象を、実大試験設備を用いて観測し、 その支配要因別にモデルを作成した。また、これらのモ デルを総合することにより、基本的には排水立て管の高 さに関する適用範囲の制約を受けない管内圧力分布計算 手法の開発を試みた。

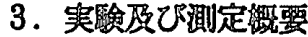

実験は、住宅・都市整備公団八王子試験場内の $108 \mathrm{~m}$ 実 験タワーと明治大学の $30 \mathrm{~m}$ 実験タワーを用いて、超高層之 中層の集合住宅を想定し、各種排水実験を行った。超高 層 $(108 \mathrm{~m})$ )場合の実験装置概要を図 1 に示す。

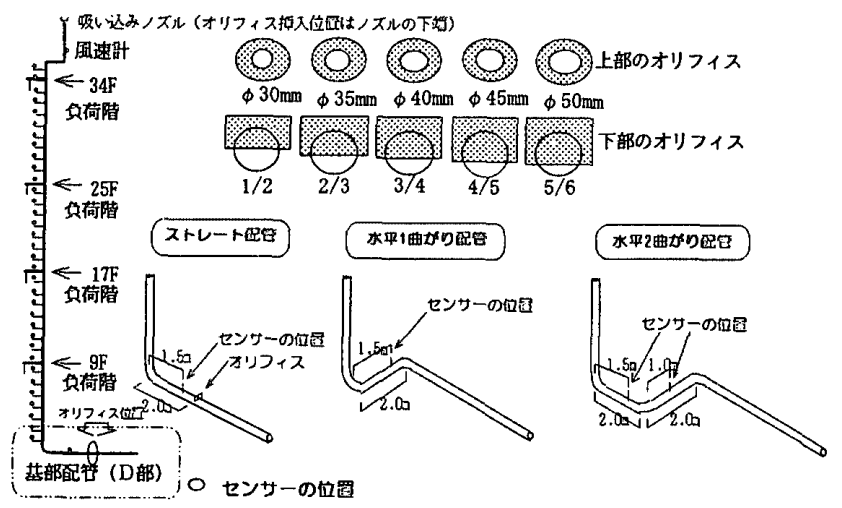

図 1 高層夕ワー実験装置概要

排水立て管は管径 $\phi 100 \mathrm{~mm}$ (JIS-DT継手を使用)、排水横 主管は管径 $\phi 125 \mathrm{~mm}$ 、排水横枝管は管径 $\phi 75 \mathrm{~mm}$ 亡した。排 水管内の圧力は、拡散半導体小型圧力変換器により排水 横枝管内の35点と横主管の2点を測定した。更に、伸頂通 気管頂部の中心風速を熱線風速計により測定し、十分発

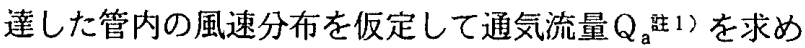
た。実験条件を表 1 に示す。

表 1 超高層タワー実験条件

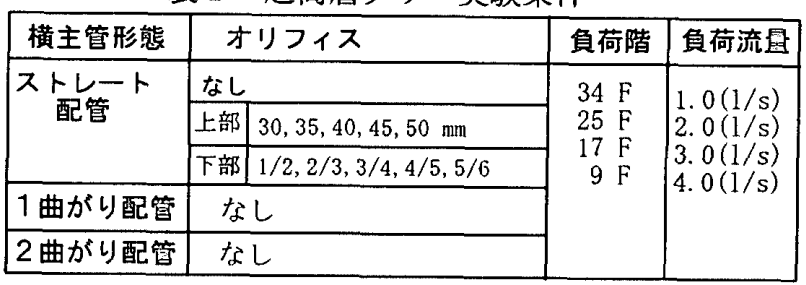

横主管の配管はストレート、1曲がり、2曲がり及び ストレート配管にオリフィス（管径の1/2、2/3、3/4、4/5、 $5 / 6$ の 5 種類）を挿人する形態であり、かつ伸頂通気管頂 部にオリフィス（内径 $\phi 30,35,40,45,50 \mathrm{~mm}$ の 5 種類）を 挿入し、通気抵抗を変化させた穾験も行った。

次に中層 $(30 \mathrm{~m})$ )場合の実験装置の概要を図 2 に示す。 


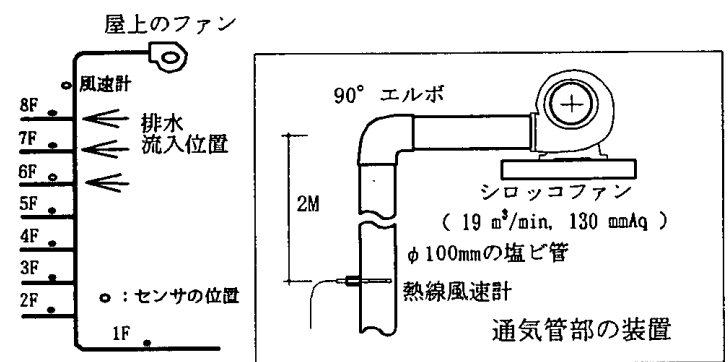

図 2 中層夕ワー実験装置概要

配管と計測機器は超高層の場合の実験装置と同様であ るが、横主管の配管はストレートのみとした。通気管の 頂部に回転数制御型の送風機を取り付け、通気流量を增 加させる場合には運転し、減少させる場合には吸込ダン パーを調整し、広い範囲の通気流量を設定して実験を 行った。

\section{4. 管内平均圧力に関する実験結果}

\section{1 超高廍実験の結果}

オリフィスなしの条件における排水立て管内時間平均 圧力分布の測定結果の例を図3、図4に示す。図3は排水負 荷高さを 9 34階の範囲で変化させ、図4は排水負荷流量を
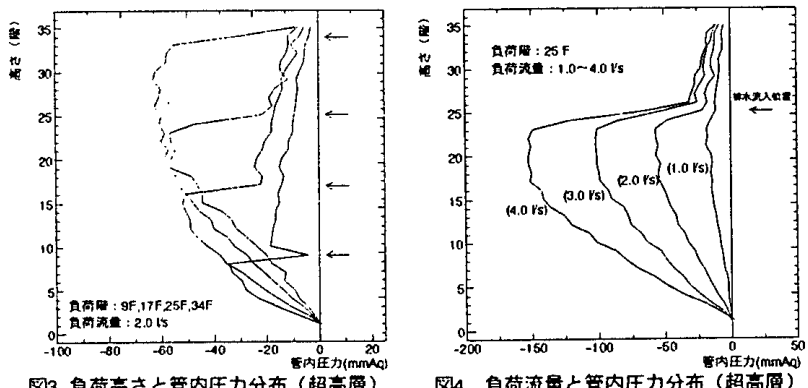

图3 負荷高さと管内压力分布（超高笛）
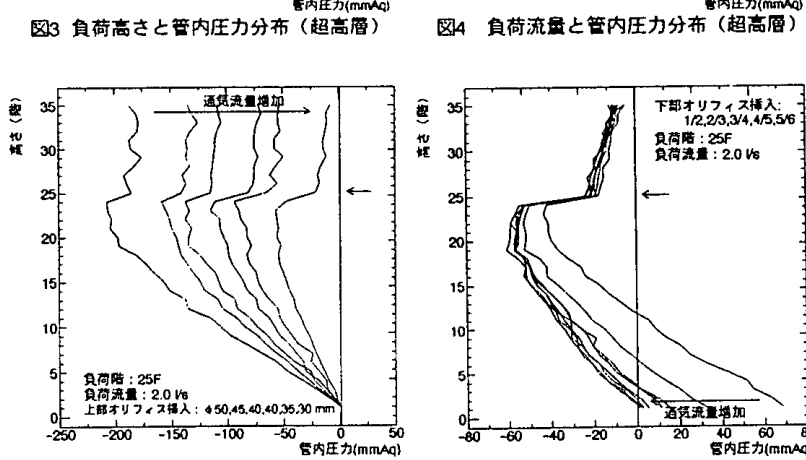

図5 上部抵抗と䇫内压力分布（超高畨）

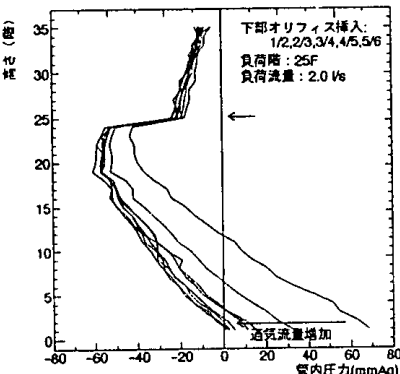

図6 下部抵抗と管内压力分布（超高層）

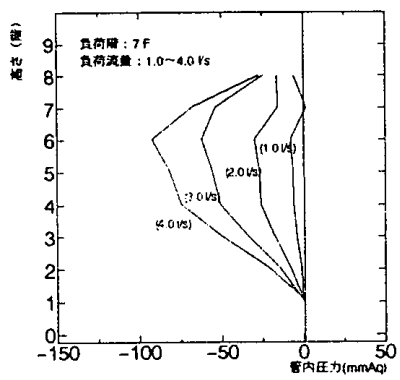

図7 負荷流量と管内压力分布 (中隐)

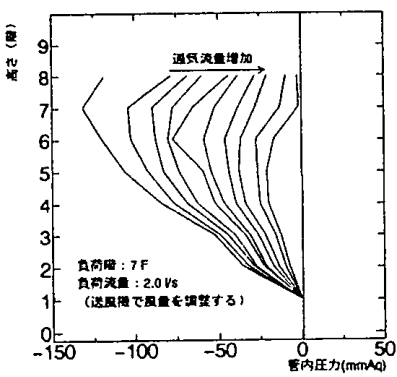

国8 通気流旦と管内圧力分布（中層）
1. 0 ～ $.01 / \mathrm{s}$ で変化させた場合における 1 箇所排水時の測 定結果の一例を示したものである。

超高層の排水の場合は、従来の $30 \mathrm{~m}$ 級の実験装置 ${ }^{3 \sim 5}$ ) で観察された最大負圧より、明らかに大きな值の出現が 確認された。また、排水負荷階が高くなるに従い、排水 階亡その下流の最大負圧発生地点の間隔が拡大する傾向 が認められ、これも $30 \mathrm{~m}$ 級の実験装置では確認されていな い。逆に、オリフィスを挿入し、通気流量を絞ると最大 負圧発生位置は負荷階に近づく傾向がある。オリフィス を挿入した条件の測定結果の例を図5、図6に示す。

\section{2 中属実験の結果}

中層実験夕ワーで、排水負荷流量を1. 0 4.0 1/sで変化 させた場合における 1 箇所排水時の測定結果を図7に示し、 伸頂通気管頂部に送風機を取り付けて、強制的に通気流 量を調整した実験結果を図8に示す。図より、王力勾配は 既往研究 ${ }^{3 \sim 4)}$ の結果と同じように、負荷流量と通気流量 $\mathrm{Q}_{\mathrm{a}}$ に強く関連していると判断される。

\section{5. 管内平均圧力分布の予測法に関する検討}

排水立て管内部に生じる圧力分布に関し、一䈯所定常 排水時の条件では、排水立て管を図 9 に示すように、4 ゾーンに区分し検討を進めた。

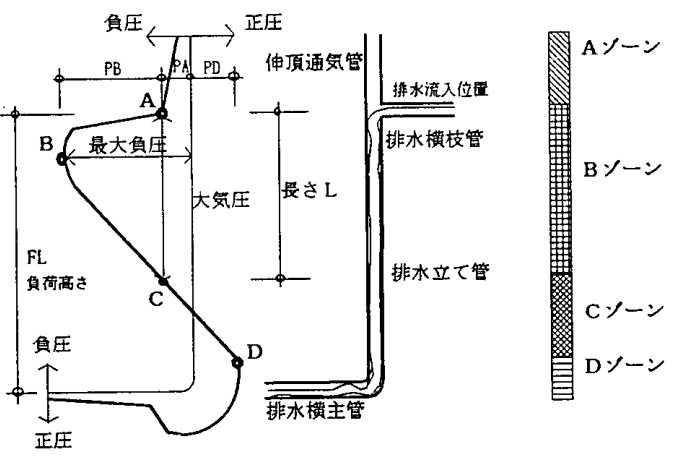

図 9 ゾーン区分の模式図

排水立て管のゾーン区分は、伸頂通気管頂部から、排 水負荷階までの空気のみが流れている部分を Aゾーン、 排水横枝管からの排水流入地点より、排水が主に通気抵 抗として作用し、管内压力が最大負圧を生じた後に、負 荷階における压力に回復するまでの垂直距離を長さ L、 この範囲をBゾーン、この地点から下流は、排水が空気 を誘引し圧力勾配が一定とみなせる領域となり、排水立 て管基部までをCゾーン、排水横主管での跳水現象等に より再び通気抵抗として作用する部分をDゾーンとした。

\section{1 $\mathrm{P}_{\mathrm{A}} 、 \mathrm{P}_{\mathrm{B}} 、 \mathrm{P}_{\mathrm{D}}$ の計算法}

Aゾーンについて Aゾーンは空気のみの流れであるた め、通常のダクトと同様に扱え、大塚らの(1)域之同様、 


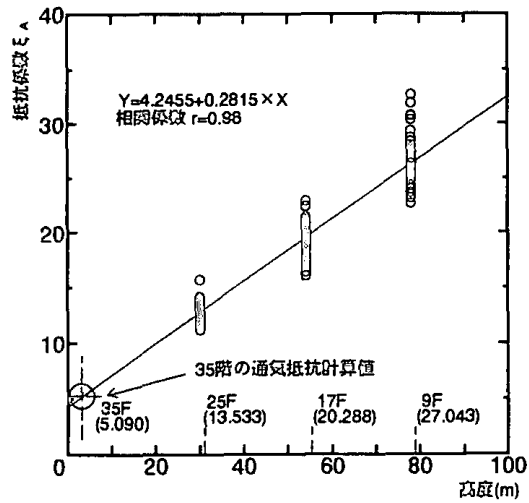

图10 Aソーン通気管部抵抗係数計算図

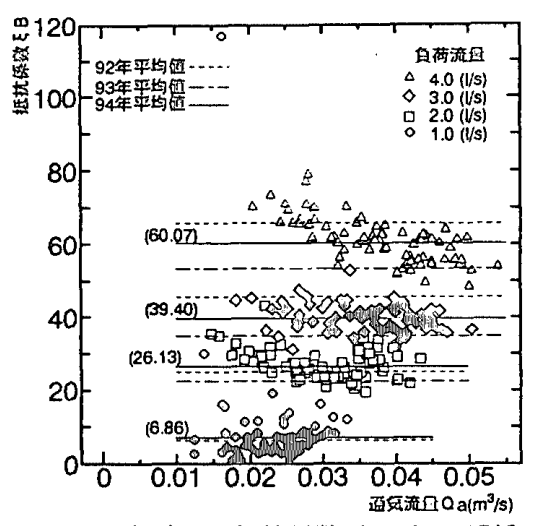

図13 通気流还之抵抗係数（Ｂ）の閔係

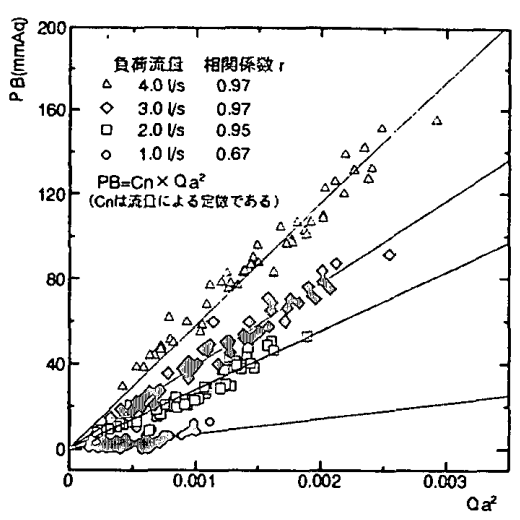

図11 Bソーーン圧カPB亡 $Q a^{2}$ の関係

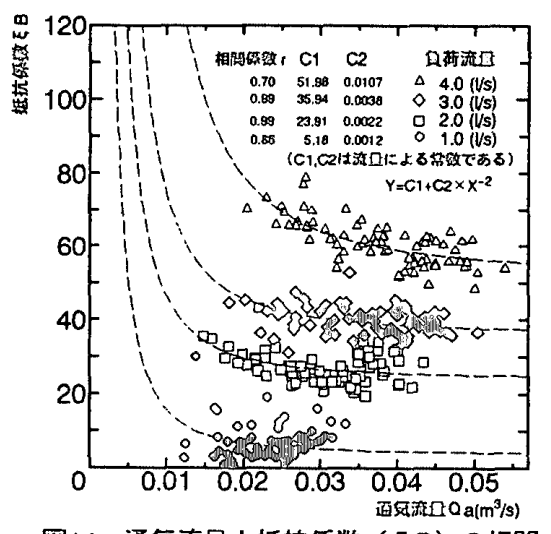

困14 通気流是之抵抗係数（Ｂ）の祸関

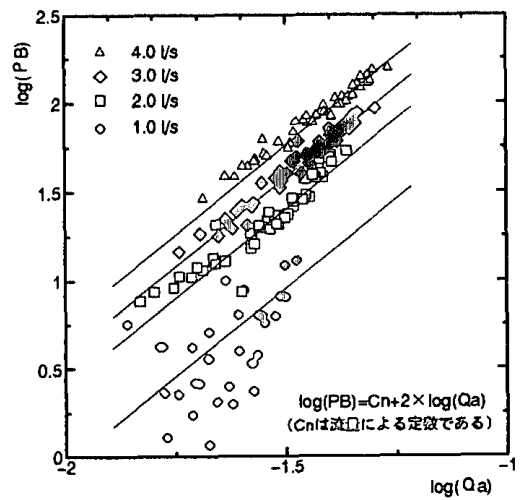

図12 Bゾーン圧カPBとQaの対数関係
以下の式(1)の適用が妥当であると考えられる。図10は排 水負荷階より上部の通気管之排水立て管の抵抗係数 $\xi_{\mathrm{A}}$ の 変化を示したものであり、 $\xi_{\mathrm{A}}$ の増加はほぼ排水管の長さ に比例する。以下では図中の回帰直線を用いて排水管内 の抵抗係数および圧力分布を計算することにした。

$$
P=\xi \times\left(\frac{\gamma}{2 g}\right) \times V_{a}^{2}
$$

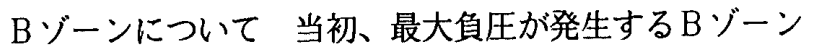
における圧力 $\mathrm{P}_{\mathrm{B}}$ には式(1)が成立し、抵抗係数 $\xi_{B}$ は通気流 量によらず、負荷流量のみの関数になると考えた。図11に $\mathrm{P}_{\mathrm{B}}$ と通気流量 $\mathrm{Q}_{\mathrm{a}}{ }^{2}$ の関係を示す。四から分かるように、 $\mathrm{P}_{\mathrm{B}}$ は $\mathrm{Q}_{\mathrm{a}}\left(\propto \mathrm{V}_{\mathrm{a}}\right)$ のほほ2 乗に比例するが、図12に示す様 に、 $\mathrm{P}_{\mathrm{B}}$ と $\mathrm{Q}_{\mathrm{a}}$ の関係を両対数軸上で表わすと、完全に2乗 とはならないことが分かる。また、抵抗係数 $\xi_{\mathrm{g}}$ と通気流 量 $\mathrm{Q}_{\mathrm{a}}$ の関係は図13に示す様に辡2)、バラツキが見られるも のの、全般的に通気流量の増加に伴い減少する傾向が認 められる。この点を考虑す机ば、式(1)の $\xi_{\mathrm{B}}$ は大塚らと同 様 $\mathrm{Q}_{\mathrm{a}}$ により変化させることが妥当と考えられる。

なお、 $\xi_{B}$ のバラツキが大きい理由としては、 $\xi_{B}$ の計 算には $\mathrm{P}_{\mathrm{B}}$ と $\mathrm{Q}_{\mathrm{a}}$ の実測值を用い、 $\mathrm{P}_{\mathrm{B}} / \mathrm{Q}_{\mathrm{a}}{ }^{2}$ の形で算出する ため、両者の測定愦差が影響を及ぼしたこと、また、最
大負圧発生位置が測定階と階の間で生じたことが考え られる。 $\xi_{\mathrm{B}}$ のQ $Q_{\mathrm{a}}$ に対する依存性を説明するために、回㷌 式を用いて実験結果を近似したものを図14に示す。この回 㷌式は $Q_{\mathrm{a}}$ が極端に小さい場合にも適用できることを意図 して作成したが、 $\mathrm{Q}_{\mathrm{a}}$ が極端に小さい場合のデー夕は十分 とは言えないため、今後、この頜域に対する実験データ の蓄積を計る必要がある。

Dゾーンについて Dゾーンは排水横主管での跳水現象 等により、Aゾーンと同様に通気抵抗として作用する部 分である。そこで、式(1)之同様の式の成立を仮定し、図 15に示す様に、一定の排水横主管形態に対応する $\mathrm{p}_{\mathrm{p}}$ 排水流量の関数としてプロットした。その結果、一定 の排水横主管形態に対し、排水流量 $Q_{\mathrm{q}}$ が同一の条件で は通気流量が異なる場合においても、ほぼ同一の なることが確認された。従って、P $\mathrm{P}_{\mathrm{D}}$ は式(1)により、計算 することにした。

\subsection{Cゾーン正力勾配の訫镜法}

立て管内圧力分布におけるCゾーン圧力勾配は、管内 の水・空気間の相互作用をモテル化して計算する手法を 考えた。一定圧力勾配となる同ゾーン中の管要素 $\Delta H$ を 模式的に図16とする。 


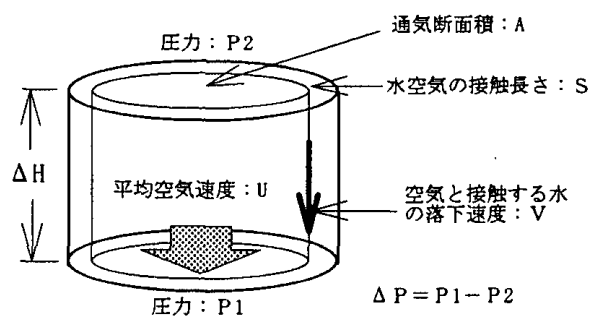

図16Ｃゾーン圧力勾配の模式図

図より、鉊直方向の力の釣り合いを考えると、水と空 気の接触面では、水の流下速度 $V$ と空気の平均速度 $U$ の 差により相互に摩擦力を受けており、空気はこの摩擦力 によって下向きの力を受ける。同時に水は空気により上 向きの力を受けることになるが、烓気と水の比重量の比 は1:1000程度と極端に相違することから、空気側が水の 運動に及ぼす影響は一定の通気流量の範囲では無視でき ると考えられる。そこで、今回は通気断面積 A、水一空 気の接触長さ $S 、$ 空気と接触する水の落下速度 $V$ は通気 流量 $\mathrm{Q}_{\mathrm{a}}$ によらず一定となることを仮定した。また、水の 落下速度は管中心付近をほぼ自由落下する部分と、環状 流となって管壁の拘束力を受ける部分では大きく異なる ことが予想されるが、今回の解析では先述したように、 管内の分布性状については立ち入らない方針で検討を進 めたため、Vは空気との摩擦に関わる水一空気接触面で の代表速度（以下はVと呼ぶ）として取り扱った。

流下する水が空気に及ぽす力を考慮するため、接触面 の単位面積当たりに作用する摩擦応力を $て 、$ 平均接触長 さを $S$ とおけば、要素中の空気に作用する摩擦力は $\tau S$ $\triangle H$ となる。一方、連続条件から管を通過する風量は一 定となるので、この力と平衡する圧力差による力が作用 し、管の通気断面積を $A$ 、上部之下部の圧力をそれぞれ $P_{N} 、 P_{2}$ とおけば、それは $\left(P_{1}-P_{2}\right) A$ 之表わされる。即ち、 力の平衡式は以下となる。

$\tau S \Delta H=\left(P_{1}-P_{2}\right) A=\Delta P \cdot A$

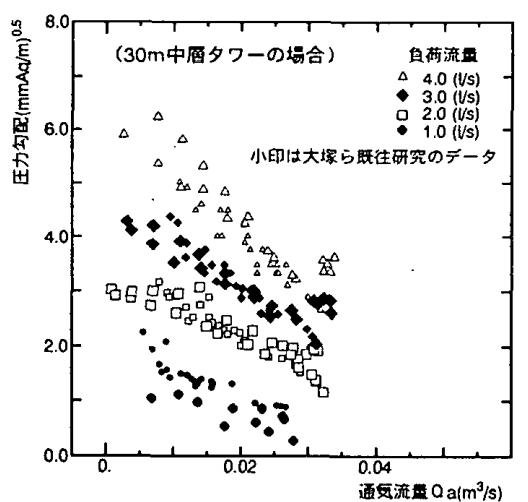

図17 圧力勾配之通気流量の相関

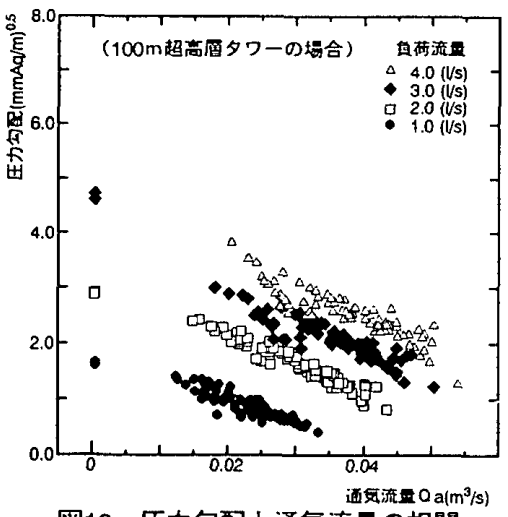

図18 压力勾配之通気流量の相関
$\frac{\Delta P}{\Delta H}=\frac{S}{A} \tau$

つまり、圧力勾配には接触長さ、通気断面積、摩擦応力 が関連する。この中で、摩擦応力 $\boldsymbol{\tau}$ は、架気と水の相対 速度に関する動圧に摩擦係数 5 を乗じて表すことが自然 と考えられるので、下式を仮定する。

$$
\tau=5 \frac{\gamma}{2 g}(V-U)^{2}
$$

式(4)のらは、戦密には管内流れのアナロジーから粗度 と相対速度 $V-U に$ 関するレイノルズ数の関数となると 考えられる。しかし、流下する水の表面の凹凸は、排水 量が極端に小さくない限りかなり大きいこと、レイノル ズ数は一般に大きいことより、実用上は一定として取り 扱ってよいと考えられる。従って、式(4)を式(3)に代入し、 下式を得る。

$$
\frac{\Delta P}{\Delta H}=\frac{S \gamma}{2 g}(V-U)^{2} \frac{S}{A}
$$

式（5）は、架気の平均速度が空気と接触する水の平均 流下速度に一致するとき、圧力勾配は 0 となることを示 しており、後にこの解积を排水流下速度の推定に用いる ことにする。式(5)は通気流量を $\mathrm{Q}_{\mathrm{a}}$ 、通気断面積を $A$ とす れば式(6)と書ける。

$$
\frac{\Delta P}{\Delta H}=\frac{S \gamma}{2 g}\left(V-\frac{Q_{a}}{A}\right)^{2} \frac{S}{A}
$$

これをさらに変形すれば、

$$
\frac{\Delta P}{\Delta H}=\frac{\varsigma \gamma}{2 g A^{2}} \cdot \frac{S}{A}\left(A V-Q_{a}\right)^{2}
$$


となるが、

$$
\alpha^{2}=\frac{5 \gamma}{2 g A^{2}} \circ \frac{S}{A}
$$

$\beta=A V$

を、先の仮定を基に排水負荷流量のみで表されるパラ メータであり通気流量には無関係であるとすれば、式(7) は

$$
\frac{\Delta P}{\Delta H}=\alpha^{2}\left(\beta-Q_{a}\right)^{2}
$$

なる形をとる。従って実験的に各排水負荷流量別に $\alpha$ 、 $\beta$ を定めることにより、通気流量と圧力勾配を関連づけ ることが可能となる。具体的なパラメー夕の決定には式 （10）を変形し、各負荷流量別に実験デー夕を

$$
\sqrt{\frac{\Delta P}{\Delta H}}=\alpha\left(\beta-Q_{a}\right)
$$

\section{なる1次式に当てはめて行うこととした。}

なお、圧力勾配の取り方については、上述の長さ $L$ を 基準として圧力勾配を取る方法を用いている。具体的に は図9において最大負压の下方で管内圧力が再び $\mathrm{P}$ 凡復帰 する点CからD点（測定の最下階）までを直線で結んで 圧力勾配を計算した。点Cが負荷階の中間点となる場合 は、その前後の負荷階から直線補間することにした。

図17、図18に圧力勾配の平方根之通気流量の関係を負荷 流量ごとに示す。図17には低層タワー及び大塚ら ${ }^{3 \sim 4)}$ の既 往研究の測定データを併せてプロットした結果を、図18に は超高層タワーの測定テータを示す。図17で注目すべき点 は今回の測定データと既往研究の測定データがほぼ同じ バラツキの範囲に収まっていることである。これは実験
装置の相違が測定デー夕に著しい影響を与えていないこ とを示唆しており、今回の測定デー夕に一般性があるこ とも物語っている。今回の中層夕ワーの測定では、オリ フィス及びファンを用いてかなり広範囲（およそ0〜0.03 $\left.\left(\mathrm{m}^{3} / \mathrm{s}\right)\right)$ の通気流量を再現した。また、図18は超高層夕 ワーのデータを示しているが、図17のデータと0.02〜 $0.03\left(\mathrm{~m}^{3} / \mathrm{s}\right)$ 範囲で通気流量が重なっており、この部分は 中層タワーで超高層タワーのCゾーン压力勾配が模擬で きる可能性を示唆している。実際超高層と中層のデー夕 を併せてプロットした図19によれば、通気流量が重なる範 囲の圧力勾配はほぼ対応している。中層タワーと超高層 タワーのデータを比較してみると、負荷流量 $2.0(1 / \mathrm{s})$ 以下 では圧力勾配の平方根はほぼ通気流量の増加に伴い、一 定の勾配で低下すると見なすことができる。しかし、 3. $0(1 / \mathrm{s})$ 以上では通気流量の増加により、勾配が緩やかに なる傾向がある。これは通気流量の変化が水の落下速度 に影響を与えることを示唆しているが、本報の範囲では 当面のモデルに従い、直線で近似することにする。各負 荷流量ごとの $\alpha 、 \beta$ 值を表2及び図20に示す。

以上の回帰直線と $\mathrm{Q}_{\mathrm{a}}$ 軸との交点は式(11)より $\beta$ を与え ることになり、 $\beta$ は式(9)の定義から通気断面積 $\mathrm{A}$ と水 一空気接触面での水の落下速度の代表値 $\mathrm{V}$ の積となる。 このようにして得られた $\beta$ 中の $\mathrm{V}$ が、排水平均速度 $\mathrm{V}_{\mathrm{q}}$ の よい近似值になっているものとすれば、管断面中の充水 面積は排水流量 $\mathrm{Q}_{\mathrm{B}}$ をVで割った値となるので、通気断面 積 $\mathrm{A}$ は管断面積を $A_{\mathrm{p}}$ として $\mathrm{A}=\mathrm{A}_{\mathrm{p}}-\mathrm{QW} / \mathrm{V}$ と表される。

表 2 実験常数 $\alpha, \beta$ 之排水の推定落下速度代表値一覧

\begin{tabular}{|c|c|c|c|}
\hline $\begin{array}{c}\text { 排水目荷流量 } \\
(1 / \mathrm{s})\end{array}$ & 実験常数 $\alpha$ & 実験常数 $\beta$ & $\begin{array}{c}\text { 排水の推定落下速度 } \\
\text { の代表值 } \mathrm{V}(\mathrm{m} / \mathrm{s})\end{array}$ \\
\hline 1.0 & 42.60 & 0.043 & 5.61 \\
\hline 2.0 & 51.93 & 0.062 & 8.15 \\
\hline 3.0 & 63.54 & 0.069 & 9.17 \\
\hline 4.0 & 75.09 & 0.073 & 9.81 \\
\hline
\end{tabular}

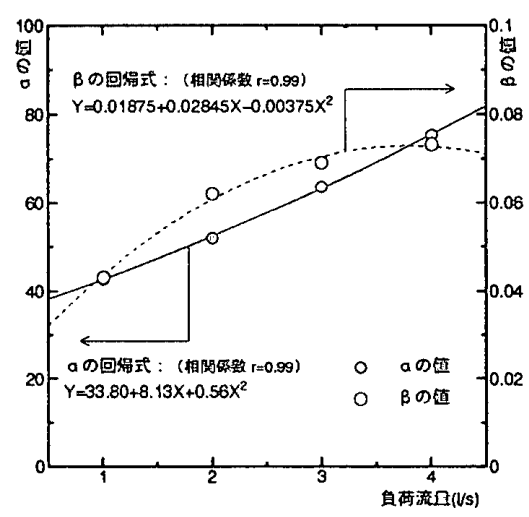

図20 実験定数 $\mathrm{a} 、 \beta$ と負荷流量の䦎係

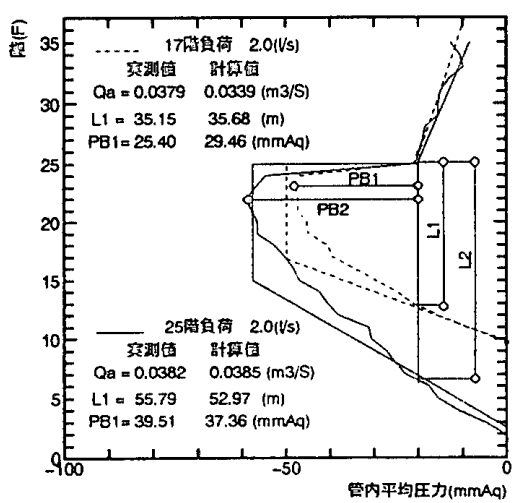

図21 PB、QaとLの関係モデル図

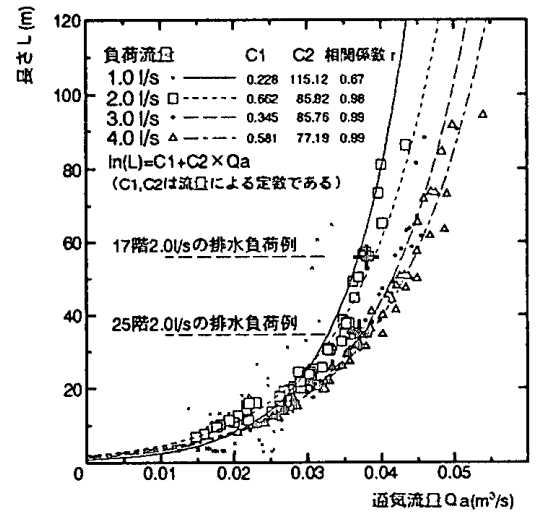

図22 通気流量 Qaと長さLの関係 
これらの関係から $\mathrm{V}$ 、の近似値であるVを試算した結果を 表 2 中に示す。なお、以上の計算の前提となっている関 係がどの程度満たされているかについては不明であるた め、計算結果の評価には注意を要する。

既往研究 ${ }^{68)}$ においては何れも水の終局速度は排水負荷 流量や立て管充水率のみで特定できると仮定しており、 通気流量の影響は考慮されていない。しかしながら、本 研究の様な超高層タワーを想定した場合、大きな通気流 量が生じる可能性があり、前述したように、通気流量が 增加するにつれて、圧力勾配か変化する傾向が見られ、 排水流下速度はその影響を受けている可能性が高い。 従って、今後は超高層タワーを想定した排水立て管内の 排水流下速度の実測や通気流量の影響も考虑に入れた理 論式の作成が必要であると思わ扚る。

\section{3 通気流量 $Q_{\mathrm{a}}$ の予測}

排水立て管で害際に排水の流れているA〜D点間を一種の 送風機之みなした場合、管内の通気流量は、排水が空気 を誘引することにより生じる現象である。本研究の予測 モデルでは、この通気流量 $Q_{a}$ を管内排水流れ現象の代表 指標とし、管内各部の圧力損失と一定圧力勾配部分によ る圧力取得がバランスする点を繰り返し計算により見出 す。

実験結果を種々検討した結果、 $\mathrm{Q}_{\mathrm{a}}$ は $\mathrm{P}_{\mathrm{B}}$ と一意的な関係 にあると判断されるが、1994年度の段階の検討6 7)では、 四21に示すようにほぼ同一負荷流量、同一通気流量であり ながら、多が異なる実駼結果に注目した。そこで、新た に負荷階直上の圧力 $\mathrm{P}$ が下流側で同じ值に回復するまで の距離 $L$ をパラメータとして検討を加えた。実験結果に より、 $\mathrm{Q}_{\mathrm{a}}$ とLの関係を示したものを図22に示すが、眓21 の排水パターンに対応する点を十字で図中に併せて示す。 図22より図21の領域は $\mathrm{Q}_{\mathrm{a}}$ の若干の変化が、Lの值に大き

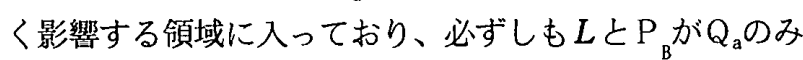
の関数で表わされることを否定するものではないことが 判明した。実際に大部分のデータでは $\mathrm{Q}_{\mathrm{a}}$ が接近した值の 場合に、図23の斜線に示すようにBゾーンの圧力分布は相 似形となっている。 $L$ と $P_{B}$ は $Q_{a}$ に対し単調増加の関係に あるから、 $Q_{a}$ による Bゾーンの圧力分布形の相似を仮定 するよ、 $\mathrm{P}_{\mathrm{B}}$ とLは $\mathrm{Q}_{\mathrm{a}}$ によらず一意的に対応するはずであ る。そこで、 $\mathrm{P}_{\mathrm{B}}$ とLの関係を示したものを図24に示し、 排水負荷流量毎に回帰を行った。 $\mathrm{P}_{\mathrm{B}}$ は流量によらずほぼ $L の 0.7$ 乘に比例することが分かった。

以上の検討結果を総合すれば、次の手順で管内圧力分 布の予測が可能である。まず、排水負荷高さ $F L$ 排水負荷 流量 $\mathrm{QW}$ 、排水横主管形態を設定する。次に適当に仮定し た $Q_{a} に$ 基づき、図14、図15、図22、式(1)、式(11)を用い

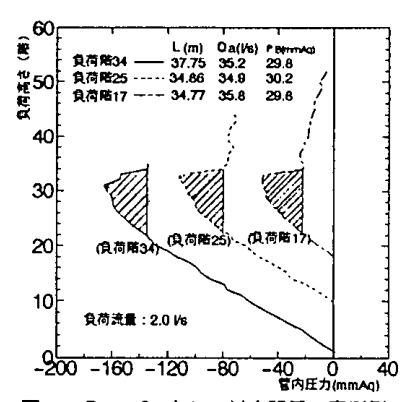

图23 PB、のaとしの対応閶係の実泚列

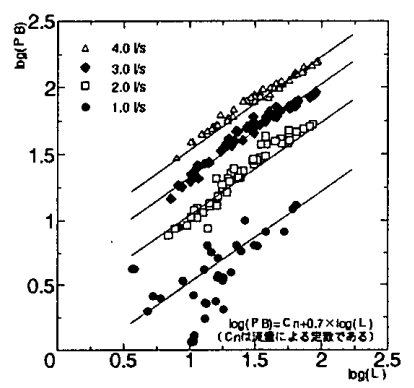

国24 Bソーン圧カPBとLの対数閶係

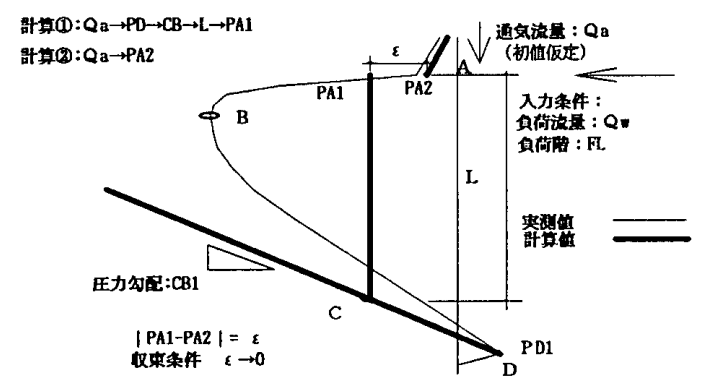

図25 管内圧力分布予測法の模式図

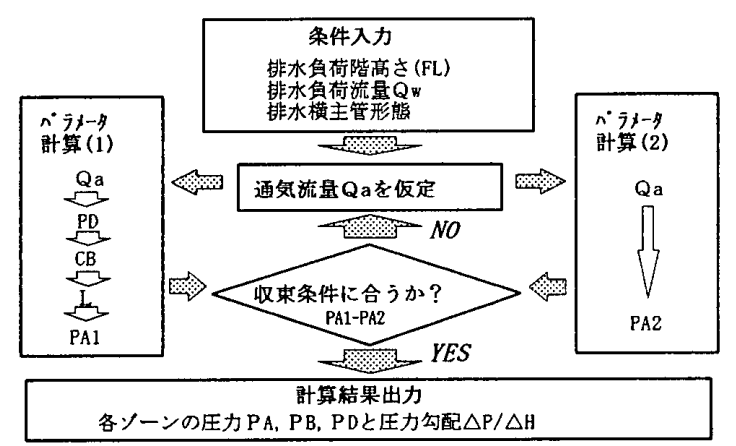

図26 管内圧力予測手法のフロー

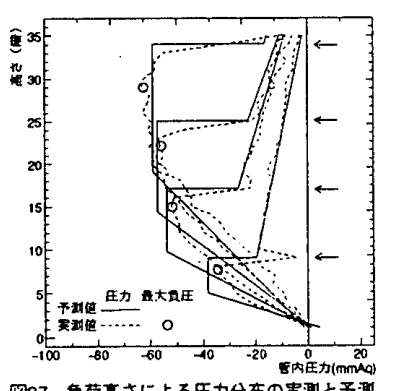

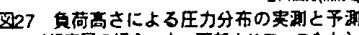
(超高屏の㙘合、上・下部オリフィスなし)

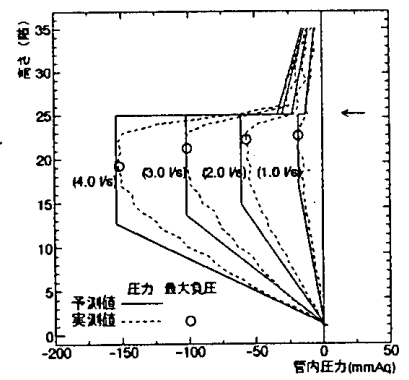

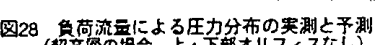

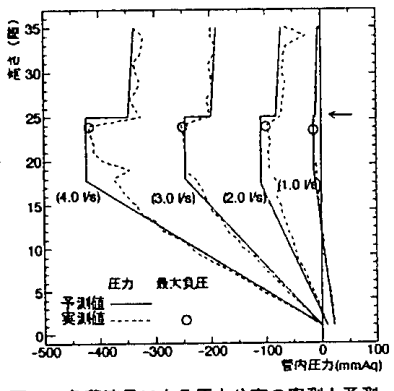

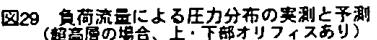

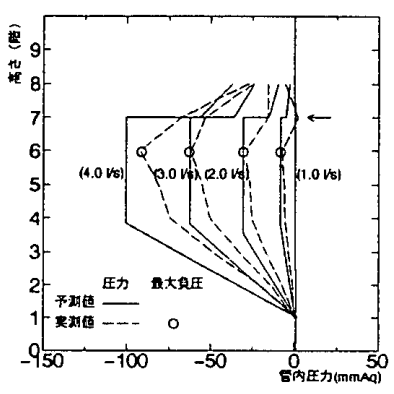

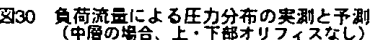




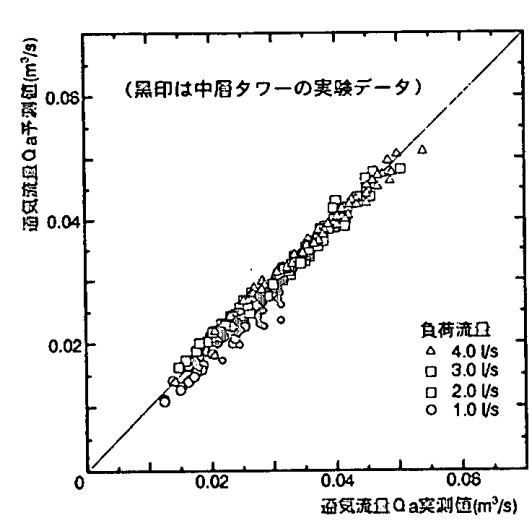

图31通気流遗Qa矛测値亡実測值の比皎

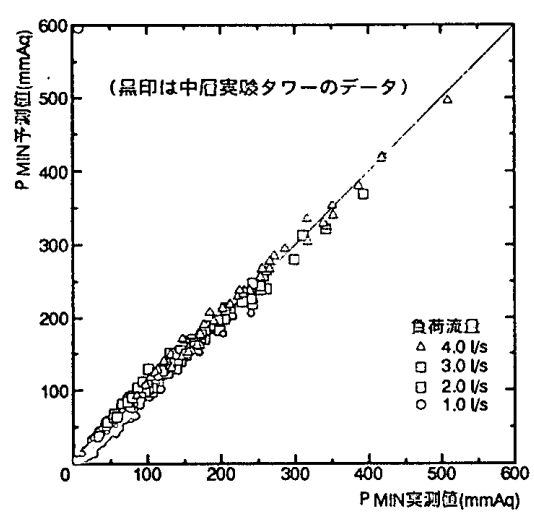

図32 Bソーン职大負圧予測値と实測値の比皎

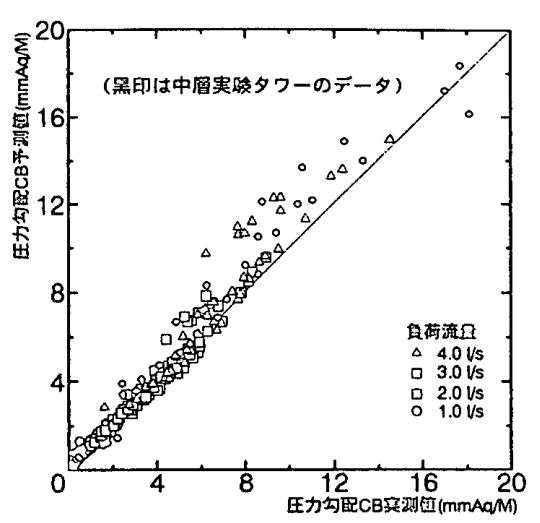

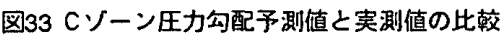

て、 $\xi_{B} 、 P_{D} 、 L 、 P_{B}$ と圧力勾配を求め、この方法によっ

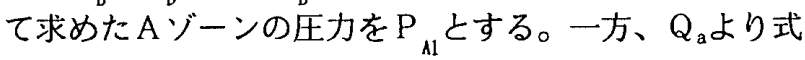
(1)からただちに同ゾーンの圧力 $\mathrm{P}{ }_{A 2}$ が求められる。一般に $\mathrm{P}_{A 1}$ と $\mathrm{P}_{N 2}$ は一致しないのて、 $\mathrm{P}_{A 1}$ となる $\mathrm{Q}_{\mathrm{a}}$ を式(1)を用い て求め、前回の $\mathrm{Q}_{\mathrm{a}}$ との平均值を新たな $\mathrm{Q}_{\mathrm{a}}$ として用いるこ とを、 $\left|\mathrm{P}_{A 1}-\mathrm{P}_{A 2}\right|<\varepsilon$ まで繰り返す。以上の通気流量と 管内圧力分布の予測の過程を図25と図26に示す。

\section{4 管内正力分布の予湘}

図27、図28と図29には超高層の場合の管内圧力分布の予 測と実測の比較例を示し、また、図30には中層の場合の管 内王力分布の予測と実測の比較例を示すが、対応はかな り良好である。通気流量が極端に小さいケースを除き、 これまでに超高層と中層タワーで行った全実験ケースに 対する通気流量 $\mathrm{Q}_{\mathrm{a}} 、 \mathrm{~B} ソ ゙ ー ン$ 最大負圧及びCゾーン压力 勾配の実測值と予測値の比較結果を図31〜図33に示す。 中層の場合の予測結果にややバラツキが大きいが、 実験範囲内（1.0 4.0 1/s）では、全体としての再現性 は非常に良好であり、本計算手法の妥当性を示している と思われる。

\section{6. まと的}

J I S 継手（DT継手）を用いた伸頂通気方式（立て 管径 $100 \mathrm{~mm}$ ）で4.0 1/sまでの排水負荷を 1 箅所から与え た場合の排水立て管内平均圧力分布に関し、本報で得ら れた結論をまとめると以下となる。

1）超高層からの排水では従来の $30 \mathrm{~m}$ 級の実験タワーで観 察された值よりも大きな負圧が生じ得る。

2）最大負王が発生する階と負荷階の間の間隔は通気流量 の增加に伴い拡大する。

3） $\mathrm{P}_{\mathrm{A}}$ は配管形態、 $\mathrm{P}_{D}$ は配管形態と負荷流量によって決ま る一定の王力損失係数 $\xi_{\Lambda} 、 \xi_{\mathrm{D}}$ に平均空気速度に関する 動圧を乗じて表すことができる。
4）Cゾーンの圧力勾配は本報で開発したモデルによれば、 その平方根は通気流量の一次関数で表すことができ、 実験との対応は比較的良好である。

5) $\mathrm{P}_{\mathrm{B}}$ 及びLは、各負荷流量ごとに、ほぼ $\mathrm{Q}_{\mathrm{a}}$ のみの関数 として表すことができた。従って、Bゾーンの圧力分 布形は、Q、が決まれば一意的に決まると考えられる。

6）以上の結果を総合して開発した圧力分布予測モデルは、 超高層、中層いずれの排水立て管内圧力分布の予測に 適用可能であり、その予測精度は、特に $\mathrm{Q}_{\mathrm{a}} \subset \mathrm{P}_{\mathrm{B}} に つ い$ て非常に良好である。 なお、今後の課題としては、

1）今回提案した予測手法は、現有実験タワー $(108 \mathrm{~m})$ より 高い条件への適用妥当性が必ずしも明確ではないため、 特にLの予測に関し、任意の排水負荷高さの条件に対 応可能な予測法について検討する必要のあること

2）中層タワーの実験データを用いて超高層条件を予測す る際の適切な実験条件の設定方法

3）Bゾーンにおける最大負圧発生位置の予測

4）複数筒所同時排水の条件への対応や、時間平均圧力分 布と圧力変動の関係解明等、が挙げられる。

\begin{tabular}{|c|c|}
\hline \multicolumn{2}{|l|}{ 記号琵： } \\
\hline$P$ : 管内压力 (mmAq) & $\xi$ : 抵抗係数 \\
\hline$P_{A}: A ソ ー 冫$ 管内壮力 $(\mathrm{mmAq})$ & $\xi_{A}: A ソ ー ン$ 抵抗係数 \\
\hline$P_{B}: B ソ ー$ 管内玨力 (mmAq) & 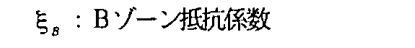 \\
\hline$P_{D}: \mathrm{D} ソ ー ン$ 管内汪力 $(\mathrm{mmAq})$ & $\xi_{\text {。 }}: \mathrm{D}$ そ一ん抵抗係数 \\
\hline y : 空気の比重星 $\left(\mathrm{kgf} / \mathrm{m}^{3}\right)$ & $\mathrm{g}$ : 重力加速度 $\left(\mathrm{m} / \mathrm{s}^{2}\right)$ \\
\hline$V_{a}:$ 空気流速 $(\mathrm{ms})$ & $V_{w}:$ 排水落下速度 $(\mathrm{m} / \mathrm{s})$ \\
\hline$Q_{\mathrm{a}}$ : 通気流量 $\left(\mathrm{m}^{3} \mathrm{~s}\right)$ & $Q_{\mathrm{w}}$ : 排水負荷流量 $\left(\mathrm{m}^{3} / \mathrm{s}\right)$ \\
\hline$A_{0}:$ 管䉼面樍 $\left(\mathrm{m}^{2}\right)$ & A : 通気断面楀 $\left(\mathrm{m}^{2}\right)$ \\
\hline $\mathrm{S}$ : 水之空気の接触長さ $(\mathrm{m})$ & $\mathrm{U}$ : 平均空気速度 $(\mathrm{m} / \mathrm{s})$ \\
\hline \multicolumn{2}{|c|}{$\mathrm{V}:$ 空気と接触する水の落下速度 $(\mathrm{a} / \mathrm{s}) \quad \varepsilon$ : 許容㒭差 } \\
\hline$\Delta H$ : 管要素長さ (m) & $\triangle \mathrm{P}$ : 管要素による压力巠（nnAq） \\
\hline$\tau:$ 摩擦応力 (㨐) & 5 : 摩擦係数 \\
\hline \multicolumn{2}{|c|}{$\alpha 、 \beta:$ 圧力勾配予測モデルの負荷流量による実呀常数 } \\
\hline \multicolumn{2}{|c|}{ 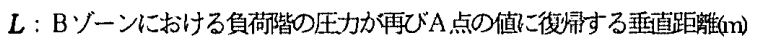 } \\
\hline$F L:$ 負荷高さ $(\mathrm{m})$ & $C B: \triangle \mathrm{P} / \triangle \mathrm{H}$ 圧力勾配 (mmAqhn) \\
\hline
\end{tabular}




\section{既辞}

本研究は住宅・都市整備公団の委託により（財）ベターリビ ング内に設けられた研究委員会：「超高層住宅における排水通 気性状に関する研究」の研究活動の一環として行われたすので あり、関係者各位に感謝の意を表します。また、文部省科学研 究費一般研究(B)「重力式排水システムにおける管内流動現象 の解明（代表者：鎌田元康）」の支援を受けた。さらに、測定 装置の試作において、こ協力頂いた須田宗夫（北斗理研），浅 野達郎（アイテクノ）, 斉藤正 (北斗電子研究所) の諸氏に, 記して感謝の意を表します。

\section{本賖文に閶保する既発表文献}

1）鈴木幸人他：集合住宅の排水システムに関する研究 （その 1 ）超高層実験タワーを用いた排水負荷実験，日本 建築学会大会学術講演梗概集，1992

2) 趙 珠娟他：集合住宅の排水システムに関する研究 （その 2）実験方法及び管内圧力分布測定結果の概要, 日 本建築学会大会学術講演梗概集, 1993

3) 田中 徹他：集合住宅の排水システムに関する研究 （その $3 ） 1$ 䇢所排水時の管内平均肚力分布とその予測法 に関する検討 1, 日本建筑学会大会学術講演梗概集, 1993

4) 符 立偉他：集合住宅の排水システムに関する研究 （その 4）1箇所排水時の管内平均压力分布とその予測法 に関する検討11，日本建筑学会大会学術講演梗概集，1993

5 ) 鄭 政利他：集合住宅の排水システムに関する研究 （その 5 ）複数䇢所排水時の管内平均王力分布と圧力変動 に関する検討，日本建筑学会大会学術講演梗概集，1993

6 ）鄭 政利他：集合住宅の排水システムに関する研究 （その 6) 実験結果の再検討及び横主管部抵抗㨉入時の予 測に関する検討, 日本建築学会大会学術講演梗概集, 1994

7 ) 田中 徹他：集合住宅の排水システムに関する研究 （その 7) 王力勾配・抵抗係数の再検討之管内压力梁動と トラップ水位変動の分析, 日本建築学会大会学術講演梗概 集, 1994

\section{参考文解}

1) Roy. B. Hunter;BMS 79 Water Distributing System for Building, 1941

2） B. J. Pink；排水立て管内気流に及ぼす立て管管長の影響 （訳），給排水設備研究会 $1-4,1978$

3）大塚雅之他；排水システム性能試験と理論体系のための基 䃈的研究（第 1 報），空気調和・衛生工学会論文集, No. 36,1988

4）大塚雅之他 ; 排水システム性能試験と理諭体系のための基 磁的研究（第 2 報），空気調和・衛生工学会論文集， No. 38,1988

5）根路銘勇他；伸頂通気方式排水システムの横枝管内王力予 測法に関する研究（その1）平均王力予測モデルの基䃈的 検討，空調調和・衛生工学会学術講演論文集，1986

6) R.S. Myly and H.N. Eaton : Capacities of Stacks in Sanitary Drainage System for Building, N. B.S. Monograph 31, 1961

7）浅野他；建築におりる排水立管の流れ性状に関する基䃈的 研究—終局速度・終局長さおよび誘引される空気流量につ いて，日本建筑学会論文報告集，No. 278，1979

8）塚越他；排水立管の流れ性状に関する実験研究，空気調 和・衛生工学会学術講演論文集, 1977

\section{墪}

1）通気流量の算出は以下の式(12)を用いた。 $Q_{a}=0.82 \times A \times V \ldots \ldots \ldots \ldots \ldots$ (12) 但し、 $Q_{a}$ : 通気流量 $\left(\mathrm{m}^{3} / \mathrm{s}\right), A$ :立て管通気断面積 $\left(\mathrm{m}^{2}\right), V$ :

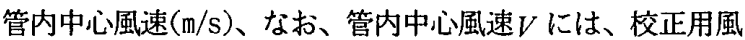
洞により、校正した熱線風速計を使用した。また、実験範

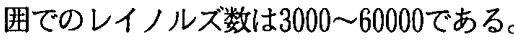

2) 年度ごとに平均值が異なる主な要团は、各年度で検討した 通気流量範囲が異なることにあるか、これに加えて測定結 果のばらつきや年度ごとに計測システムを一部更新してき たことの影響が考えられる。そこで、本報では計測システ ムの確立を目標として行った初年度のデータを除き、 93, 94年度デー夕を分析の対象とした。 